\title{
A Study of Language Learning Strategies Used by EFL Learners in Iran: Exploring Proficiency Effect on English Language Learning Strategies
}

\author{
Maryam Khosravi \\ Sheikhbahaee University, Baharestan, Isfahan, Iran \\ Email: Maryamkhosravi78@yahoo.com
}

\begin{abstract}
The present study was carried out to investigate whether there is any relationship between the language learners' general language proficiency level and language learning strategies at elementary and intermediate level in Iran. The research tried to find out how learners' proficiency level influences language learning strategies employed by learners. In addition the study seeks to identify the most and the least used strategies by the above mentioned learners. Steps on measuring this factor are discussed in the research. Participants are adult language learners, about 100 Iranian men and women aged 13-48 who completed questionnaires provided by the researcher. These learners were in two different general learning levels (elementary and intermediate) of English language learning and their age and education are varied. According to the results of the SILL, the findings indicate that the use of cognitive strategies had the strongest relation to English proficiency and higher proficiency EFL students use cognitive, metacognitive and social strategies more often than students with lower proficiency level proficiency. In contrast, there is no significant difference in the use of memory strategies between higher and lower proficiency EFL students. In addition, both higher and lower proficiency EFL students use compensation strategies more often than other strategies.
\end{abstract}

Index Terms-learning strategies, language proficiency, cognitive, metacognitive, SILL, EFL

\section{INTRODUCTION}

Over the past few decades, researchers and language teachers noticed that some learners seem to be successful in second or foreign language learning regardless of teaching methods and techniques. Therefore, a considerable number of researchers have shifted their focus from teaching methods or techniques to language learning strategy use. Language learning strategies are specific actions or techniques that learners use to assist their progress in developing second or foreign language skills (Oxford, 1990). Language learning strategies are believed to play a vital role in learning a second language, as they may assist learners in mastering the forms and functions required for reception and production in the second language and thus affect achievement (Bialystok, 1979). Many researchers have suggested that the conscious use of language learning strategies makes good language learners (Naiman, Frohlich \& Todesco, 1975; Wenden, 1985). Researchers believe that strategies of successful language learners can provide a basis for aiding language learners (Rubin, 1975; Reiss, 1983). Therefore, if language teachers know more about effective strategies that successful learners use, they may be able to teach these effective strategies to less proficient learners to enhance these learners' language skills.

Therefore the researcher hopes that insights into Iranian EFL learners' use of English learning strategies could provide information for researchers and educators that will furnish them with knowledge about how to enhance and assist the students in the use of language learning strategies.

\section{LITERATURE REVIEW}

\section{A. Definitions of Language Learning Strategies}

"Strategy", from the ancient Greek term strategia, refers to generalship or the art of war. In a more specific sense, strategy entails the optimal management of troops, ships or aircraft in a planned campaign. "Tactics" is different but related to strategies, which are tools to achieve the success of strategies. Moreover, the two expressions share some basic concepts: planning, competition, conscious manipulation and movement toward a goal. In nonmilitary settings, the concept of strategy has been applied to the non-adversarial situations, where it has come to mean a plan, step or an action is taken for achieving a specific objective (Oxford, 1990). Oxford (1990) stated that strategies are particularly important for language learning "because they are tools for active, self-directed involvement, which is essential for developing communicative competence" (p. l). Because of its significance, learning strategies have been extensively employed in the educational field. In defining the language learning strategy, "different researchers use different terms 
and different concepts" (Oxford \& Crookall, 1989, p.414); therefore, a great number of researchers have formulated their own definitions which will be discussed in the followings.

Cohen (1998) defines Language Learning Strategies as "those processes which are consciously selected by learners and which may result in action taken to enhance the learning or use of a second or FL, through the storage, recall and application of information about that language" (p.4). O'Malley \& Chamot (1990) consider strategies as tools for active, self-directed involvement needed for developing FL communicative ability.

Schemeck (1988) stated, strategy is "the implementation of a set of procedures (tactics) for accomplishing something" and learning strategy is "a sequence of procedures for accomplishing learning" (p.5). Weinstein and Mayer (1986) proposed learning strategies as "behaviors and though that a learner engages in during learning and that are intended to influence the learner's encoding process" (p.315).

Nisbet (1986) offered another definition of language learning strategies as "always purposeful and goal-oriented, but perhaps not always carried out at a conscious or deliberate level. They can be lengthy or so rapid in execution that it is impossible for the learner to recapture, recall or even be aware that one has used a strategy" (p.25).

Oxford and Crookball (1989) defined language learning strategies as "steps taken by the learners to aid the acquisition, storage, and retrieval of information" (p.404). They noted that strategies may be used consciously but they can also become habitual and automatic with practice. Similarly, Oxford (1990) claimed "learning strategies are steps taken by students to enhance their own learning" (p.1). She proposed a more specific definition of learning strategies as "specific actions taken by the learner to make learning easier, faster, more enjoyable, more self-directed, more effective, and more transferable to new situation" (p. 8)

\section{B. The Importance of Language Learning Strategies}

Research on language learning strategies began with strategies of the "good language learner" by Rubin (1975) and Stern (1975). From these initial research efforts, numerous researchers have attempted to emphasize the importance of language learning strategy use by successful language learners (e.g. Abraham \& Vann, 1987, 1990; Chamot \& Kupper, 1989; Naiman, Frolich, Stern, and Todesco, 1978; O'Malley \& Chamot, 1990; Oxford et al., 1989, 1993, 1995; Politzer \& McGroarty, 1985; Reiss, 1983). They noted that, generally speaking, more successful learners employed language learning strategies more frequently and more appropriately than did less successful learners. The researchers believe that language learning strategy plays a significant role in L2/FL learning, due to the fact that language learning strategies that can help learners to facilitate the acquisition, storage, retrieval or use of information and increase selfconfidence.

\section{Classification of Language Learning Strategies}

In Oxford's (1990) study, she synthesized prior study results and came up with a language learning strategy system (see Table 1). Six categories, including memory strategies, cognitive strategies, compensation strategies, metacognitive strategies, affective strategies and social strategies were divided into two major types: direct and indirect, and each class contains three categories. Direct strategies help learners to learn the target language directly; indirect strategies help learners to support and manage language learning without directly involving the target language. Direct strategies are subdivided into memory, cognitive, and compensation strategies; indirect strategies are subdivided into metacognitive, affective, and social strategies. In this study, I will use Oxford's (1990) classification as described below (Oxford, 1990, p. 8):

TABLE I.

OXFORD'S LANGUAGE LEARNING STRATEGY SYSTEM (OXFORD, 1990, P.17)

\begin{tabular}{|c|c|c|}
\hline Type & Primary strategies & Secondary strategies \\
\hline \multirow[t]{3}{*}{$\begin{array}{l}\text { Direct } \\
\text { Strategies }\end{array}$} & 1.Memory strategies & $\begin{array}{l}\text { A. Creating metal linkages } \\
\text { B. Applying images and sounds } \\
\text { C. Reviewing well } \\
\text { D. Employing action }\end{array}$ \\
\hline & 2. Cognitive strategies & $\begin{array}{l}\text { A. Practicing } \\
\text { B. Receiving and sending messages } \\
\text { C. Analyzing and reasoning } \\
\text { D. Creating structure for input and output }\end{array}$ \\
\hline & 3. Compensation strategies & $\begin{array}{l}\text { A. Guessing intelligently } \\
\text { B. Overcoming limitations in speaking and writing }\end{array}$ \\
\hline \multirow[t]{3}{*}{$\begin{array}{l}\text { Indirect } \\
\text { Strategies }\end{array}$} & 1.Metacognitive strategies & $\begin{array}{l}\text { A. Centering your learning } \\
\text { B. Arranging and planning your learning } \\
\text { C. Evaluating your learning }\end{array}$ \\
\hline & 2. Affective strategies & $\begin{array}{l}\text { A. Lowering your anxiety } \\
\text { B. Encouraging yourself } \\
\text { C. Taking your emotional temperature } \\
\end{array}$ \\
\hline & 3. Social strategies & $\begin{array}{l}\text { A. Asking questions } \\
\text { B. Cooperating with others } \\
\text { C. Empathizing with others }\end{array}$ \\
\hline
\end{tabular}


Of all the variables that affect the use of language learning strategies, proficiency is regarded as one of the salient variables that result in differences in strategy use. If the strategies employed by students with different proficiency could be identified, more insights will be gained into the learning process of individual learners and the characteristics of learners with different proficiency level. Hence, a study of the relationship between language learners' proficiency level and their use of language strategies is necessary to provide more insights into this issue.

Chamot and Kupper (1989) asserted that high proficiency learners know how to use appropriate strategies to reach their learning goals, while low proficiency learners are less expert in their strategy use and choice. Oxford (1985) claimed that successful language learners use a wide range of strategies that are most appropriate for their learning tasks. MacIntyre (1994) also indicated that second language learners may use strategies that make their communication more effective, informative and persuasive when they attain certain proficiency. Yang (1994) stated that perceived proficiency levels have a significant effect on student's use of learning strategies. The better students perceive their language proficiency, the more often they use various learning strategies to assist them in learning English. It seems that language proficiency is commonly recognized as a determinant of strategy use by more and more students.

The factor, proficiency level, was addressed in studies related to language learning strategy by some researchers. In a study of 70 high-school age students enrolled in ESL classes from three high schools in an Eastern metropolitan area in the United States, the authors (O’Malley et al., 1985) revealed that intermediate level students tended to use proportionally more metacognitive strategies than students with beginning level proficiency. Chamot, O'Malley, Kupper and Impink-Hernandez (1987) found that cognitive strategy use decreased and metacognitive strategy use rose as the foreign language course level increased, but social affective strategy use remained very low across all course levels. In addition, according to some research, proficiency level and gender affect the choice of language learning strategies (Politzer, 1983; Oxford and Nyikos, 1989; Ehrman and Oxford, 1989; Oxford, 1993; O'Malley et al., 1985; Chamot, O’Malley, Kupper and Impink-Hernandez, 1987).

\section{Research Questions and Hypotheses}

Proficiency level is one of the factors to affect the choice of language learning strategies. The purpose of this study is to investigate the difference in the extent and types of language learning strategy use between higher and lower proficiency EFL students. This study was designed to determine: (1) whether a statistically significant difference exists in the extent of language learning strategy use between higher and lower proficiency EFL students; (2) the strength of the effect of language learning strategy use on English proficiency. The research questions and null hypotheses are stated as follows:

(1) Is there any difference in the extent of language learning strategy use between higher and lower proficiency EFL students?

H01: There is no significant difference in mean language learning strategy average total score of higher proficiency EFL students and lower proficiency EFL students.

H02: There is no significant difference in mean language learning strategy average subscores of higher proficiency EFL students and lower proficiency EFL students.

(2) Does the reported use of language learning strategies significantly relate to English proficiency?

H03: There is no significant relationship between the use of the six types of language learning strategies and the scores on English proficiency test among EFL students.

\section{METHOD}

\section{A. Participants}

The targeted population was intermediate and elementary-level adult English language learners at Nahid Language Institute (here after NCI) in Shahreza. Random selection was used in the sampling process of this research study. Participants were adult language learners, about 100 men and women aged 13-48 who completed questionnaires and were examined. These learners were in different learning levels at NCI and their age and education were varied. Students entering the program were mother tongue speakers of Persian. Of the 100 returned questionnaires, 17 questionnaires were discarded as invalid, those either incomplete or did not follow the answering instruction. Table 2 summarizes the profile of participants.

TABLE II

Profile of Participants

\begin{tabular}{|l|l|l|}
\hline Group & Number & Percent \\
\hline Higher proficiency (intermediate level) & 40 & $48 \%$ \\
\hline Lower proficiency (elementary level) & 43 & $52 \%$ \\
\hline
\end{tabular}

\section{B. Instruments}

\section{SILL (Strategy Inventory for Language Learning)}

To collect data on language learners' learning strategies, a Persian translation of English learning strategy questionnaire, which was based of Oxford's (1990) Strategy Inventory for Language Learning (SILL), was administered 
to the participants. The SILL was chosen for this study because it is "perhaps the most comprehensive classification of learning strategies to date" (Ellis, 1994, p.539). Version 7.0 of the SILL is a self-report instrument that assesses the frequency with which the subjects use a variety of techniques for foreign language learning. It contains 50 items, and characterized into six subscales: (a) memory strategies (item 1 to9), (b) cognitive strategies (items10 to 23), (c) compensation strategies (items 24 to 29), (d) metacognitive strategies (items 30 to 38), (e) affective strategies (items 39 to 44), (f) social strategies (45 to 50). These SILL 50 items are evaluated on a five-point Likert scale ranging from 1 to

5. The number indicates how often the learner uses the strategies.

Never or almost true of me $\quad=1$

Generally not true of me $\quad=2$

Somewhat true of me $\quad=3$

Generally true of me $\quad=4$

Always or almost always true of me $=5$

A sample of the questionnaire as well as its translation is available on Appendix 1.

\section{General English proficiency determination}

The curriculum at NCI contains twenty levels of English study which are subdivided into Elementary Levels (1-8), Intermediate Levels (9-16), and Advanced Levels (17-20). Following the purpose of identifying the strategies which are utilized by EFL learners into the first two categories (elementary and intermediate), we focus on the scores these learners get on the final-term achievement tests taken at the end of the levels in which they study. Since the required score to pass the level is the minimum of 70 out of 100, we are sure that the learner is in the right level of English study. These scores are considered as the proficiency scores (the proficiency level of the participants) in the present study. The test includes four parts: listening, reading, writing and speaking. In listening test, it contains two sections: 10 questions on question-response and 10 questions on short conversation. The reading test includes two passages and 10 questions on reading comprehension. The writing test consists of twenty question items testing students' vocabulary knowledge and twenty question items checking their knowledge of the grammar in the language. The total scores on the four skills, which are considered as the learners' scores in General English Proficiency Test (GEPT), were used to analyze the relationship between language learning strategy use and English proficiency.

\section{DATA ANALYSIS}

In this study, to test Hypothesis One and Hypothesis Two, an independent samples t-test was used to evaluate the differences in language learning strategy use between higher and lower proficiency EFL students. Furthermore, to test Hypothesis Three, a multiple regression was used to evaluate the effect of language learning strategy use on English proficiency.

\section{RESULTS}

This study examined three hypotheses which relate to the extent and types of language learning strategies used by higher and lower proficiency EFL students and their English proficiency. The report of the results consists of two parts:

1. Independent samples t-test

2. Multiple regression analysis

The data in this study obtained from the SILL and the GEPT test were tabulated and analyzed using Statistical Package for Social Sciences (SPSS) for Windows.

Students, who completed the questionnaire, responded as is shown in table 3. To compare the mean of memory strategies among elementary and intermediate students we use $t$-test. So we consider this statistical hypothesis.

$\mathrm{H} 0$ : There is no difference in using the memory strategies in elementary and intermediate students.

$\mathrm{H}$ 1: Using the memory strategies in elementary and intermediate students is different.

To show these in mathematical way, we can write:

H0: $\mathrm{M} 1=\mathrm{M} 2$

H1: M1 \# M2

(M1 is the mean of memory scores in elementary students. M2 is mean of memory scores in intermediate students).

Table 3 relates to English proficiency level and presents data related to the overall SILL mean score as well as the mean scores on the six types of strategies for higher and lower proficiency EFL students. In addition, it reveals the result of the independent samples $t$-test. 
TABLE III.

MEAN REPORTED FREQUENCY OF LANGUAGE LEARNING STRATEGY FOR ALL STUDENTS

\begin{tabular}{|c|c|c|c|c|c|}
\hline Strategies & Group & Mean & SD & T value & $P$ value \\
\hline \multirow[t]{2}{*}{ Memory } & elementary & 27.6279 & 5.11777 & \multirow[t]{2}{*}{-.613} & \multirow[t]{2}{*}{.541} \\
\hline & intermediate & 28.3250 & 5.22512 & & \\
\hline \multirow[t]{2}{*}{ Cognitive } & elementary & 42.5581 & 9.02721 & \multirow[t]{2}{*}{-.209} & \multirow[t]{2}{*}{.835} \\
\hline & intermediate & 42.9500 & 8.03502 & & \\
\hline \multirow[t]{2}{*}{ Compensation } & elementary & 19.2093 & 3.93736 & \multirow[t]{2}{*}{.123} & \multirow[t]{2}{*}{0.902} \\
\hline & intermediate & 19.1000 & 4.14358 & & \\
\hline \multirow[t]{2}{*}{ Metacognitive } & elementary & 32.8605 & 9.29050 & \multirow[t]{2}{*}{.584} & \multirow[t]{2}{*}{0.561} \\
\hline & intermediate & 31.6250 & 9.92972 & & \\
\hline \multirow[t]{2}{*}{ Affective } & elementary & 15.4651 & 4.78265 & \multirow[t]{2}{*}{-0.90} & \multirow[t]{2}{*}{0.371} \\
\hline & intermediate & 16.5000 & 5.62504 & & \\
\hline \multirow[t]{2}{*}{ Social } & elementary & 21.0233 & 4.59549 & \multirow[t]{2}{*}{0.406} & \multirow[t]{2}{*}{0.686} \\
\hline & intermediate & 20.6250 & 4.34822 & & \\
\hline
\end{tabular}

To test hypothesis, $t$-test was used to determine the significance of differences. If p-value is less than alpha, we reject the null hypothesis; so we can see these results from the p-values of table 4:

\begin{tabular}{|c|c|c|c|c|c|}
\hline \multicolumn{6}{|c|}{$\begin{array}{c}\text { TABLE IV. } \\
\text { COEFFICIENTS }\end{array}$} \\
\hline \multirow[b]{2}{*}{ Model } & \multicolumn{2}{|c|}{ Unstandardized Coefficients } & \multirow{2}{*}{\begin{tabular}{|l}
$\begin{array}{l}\text { Standardized } \\
\text { Coefficients }\end{array}$ \\
Beta \\
\end{tabular}} & \multirow[b]{2}{*}{$\mathrm{t}$} & \multirow[b]{2}{*}{$\mathrm{P}$ value } \\
\hline & B & Std. Error & & & \\
\hline (Constant) & 79.168 & 7.252 & & 10.917 & .000 \\
\hline Memory & .146 & .237 & .080 & .615 & .540 \\
\hline Cognitive & -.158 & .156 & -.144 & -1.012 & .315 \\
\hline Compensation & .107 & .339 & .046 & .315 & .754 \\
\hline Metacognitive & .367 & .163 & .375 & 2.248 & .027 \\
\hline Affective & -.524 & .265 & -.291 & -1.974 & .052 \\
\hline Social & .021 & .287 & .010 & .073 & .942 \\
\hline
\end{tabular}

P-value (memory): 0.540 is not less than alpha, so we can not reject the H0; it means that there is no significant difference in using memory strategies in elementary and intermediate students.

For the other strategies, also the same results can be seen (there is no significant difference in using these strategies and proficiency level). This means the students use these strategies irrelevant from their proficiency levels.

"Does the reported use of language learning strategies significantly relate to proficiency level?"

A multiple regression was used to form the model of the relationship between language learning strategy use and English proficiency. The regression analysis reveals how a change in one variable $(\mathrm{X})$ relates to a change in the other variables (Y). In specific, the stronger the correlation between X and Y, the more accurately Y (dependent variable) can be predicted from $\mathrm{X}$ (independent variable), and vice versa.

Notice that dependent variable is Y (GEPT) and learning strategies are independent variables.

The multiple regression equation in this study is as follows:

$\mathrm{Y} i=\beta 0+\beta 1 \mathrm{X} 1 i+\beta 2 \mathrm{X} 2 i+\beta 3 \mathrm{X} 3 i+\beta 4 \mathrm{X} 4 i+\beta 5 \mathrm{X} 5 i+\beta 6 \mathrm{X} 6 i+e i$

$Y$ : scores on English proficiency test

$\mathrm{X} 1 \sim \mathrm{X} 6$ : scores on six types of strategies respectively

$\beta 0$ : intercept

$\beta 1 \sim \beta 6$ : the strength of the effect of language learning strategy use on the scores of the proficiency test

$e$ : error term

$\mathrm{B} i \quad I=1,000,6$ regression coefficients

The regression model in first step is (table 4):

$\mathrm{Y}=79.168+0.146 \mathrm{X} 1-0.158 \mathrm{X} 2+0.107 \mathrm{X} 3+0.367 \mathrm{X} 4-0.524 \mathrm{X} 5+0.021 \mathrm{X} 6+e i$

The next step is checking the significance of regression coefficients ( $\beta$ s). Outputs of table 4 show that "metacognitive" and "affective" strategies were related to GEPT scores.

While ANOVA table is a useful test of the model's ability to explain any variation in the dependent variable, it does not directly address the strength of the relationship. 
TABLE V.

MODEL SUMMARY ${ }^{\mathrm{b}}$

\begin{tabular}{|l|l|l|l|l|}
\hline Model & R & R Square & Adjusted R Square & Std. Error of the Estimate \\
\hline 1 & $.313^{\mathrm{a}}$ & .098 & .027 & 9.22542 \\
\hline
\end{tabular}

a. Predictors: (Constant), Social, Compensation, Memory, Affective, Cognitive, Metacognitive

b. Dependent Variable: GEPT

$\mathrm{R}$ the multiple correlation coefficients, is the linear correlation between the observed and model predicted values of the dependent variable. Its larger value indicates a strong relationship. In this table $\mathrm{R}$ is 0.313 , so this relationship is weak. R-Square, the coefficient of determination, is the squared value of the multiple correlation coefficients. R Square in this table is 0.098 and shows that less variation in GEPT is explained by the model. If we omit the coefficients that are not significant, the amount of R and R-Square and Adjusted R Square will increase.

\begin{tabular}{|c|c|c|c|c|c|c|}
\hline \multicolumn{7}{|c|}{$\begin{array}{l}\text { TABLE VI. } \\
\text { ANOVA }^{\mathrm{b}}\end{array}$} \\
\hline \multicolumn{2}{|c|}{ Model } & Sum of Squares & df & Mean Square & $\mathrm{F}$ & Sig. \\
\hline \multirow[t]{3}{*}{1} & Regression & 704.369 & 6 & 117.395 & 1.379 & $.234^{\mathrm{a}}$ \\
\hline & Residual & 6468.233 & 76 & 85.108 & & \\
\hline & Total & 7172.602 & 82 & & & \\
\hline
\end{tabular}

b. Dependent Variable: GEPT

TABLE VII.

COEFFICIENTS $^{\mathrm{a}}$

\begin{tabular}{|c|c|c|c|c|c|c|}
\hline & & Unstand & efficients & Standardized Coefficients & \multirow[b]{2}{*}{$\mathrm{t}$} & \multirow[b]{2}{*}{ Sig. } \\
\hline \multicolumn{2}{|c|}{ Model } & B & Std. Error & Beta & & \\
\hline \multirow[t]{7}{*}{1} & (Constant) & 79.168 & 7.252 & & 10.917 & .000 \\
\hline & Memory & .146 & .237 & .080 & .615 & .540 \\
\hline & Cognitive & -.158 & .156 & -.144 & -1.012 & .315 \\
\hline & Compensation & .107 & .339 & .046 & .315 & .754 \\
\hline & Metacognitive & .367 & .163 & .375 & 2.248 & .027 \\
\hline & Affective & -.524 & .265 & -.291 & -1.974 & .052 \\
\hline & Social & .021 & .287 & .010 & .073 & .942 \\
\hline
\end{tabular}

The ANOVA table tests the acceptability of the model from a statistical perspective. The regression row displays information about the variation accounted for by the model. The residual row displays information about the variation that is not accounted for by the model. The regression and residual sums of squares are not equal which indicates that most of the variation in the GEPT is not explained by the model. The sig (p-value) in this table shows that some of the independent variables must be canceled. The significant value of F-statistic is more than 0.05 which means the variation explained by the model is not suitable.

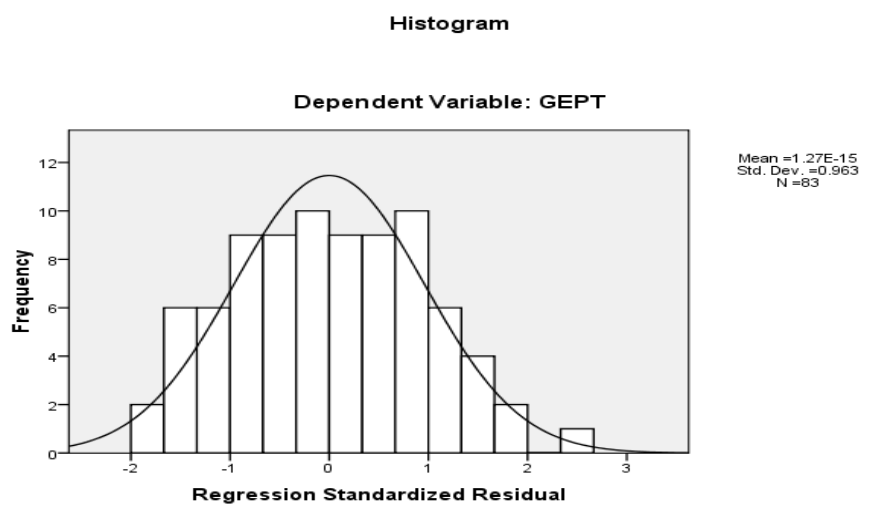

A residual is the difference between the observed and model predicted values of the dependent variable. The residual for a given product is the observed value of the error term for that product. This histogram shows that residuals are normal. (P-p plot shows the normality of residuals, too). 
Normal P-P Plot of Regression Standardized Residual

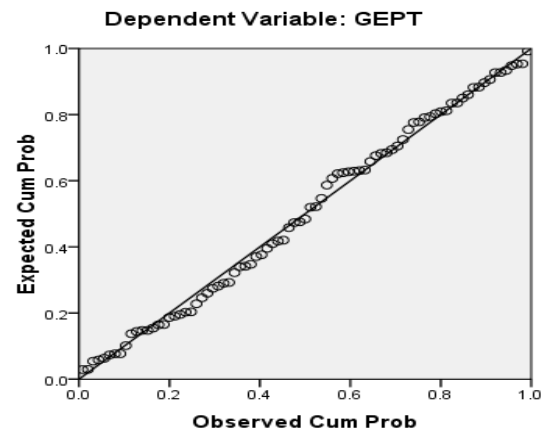

The plot of residuals by the predicted values shows that variance of errors increases with increasing predicted values.

TABLE VIII.

Coefficient Correlations

\begin{tabular}{|c|c|c|c|c|c|c|c|}
\hline Model & & Social & Compensation & Memory & Affective & Cognitive & Metacognitive \\
\hline \multirow[t]{6}{*}{1 Correlations } & Social & 1.000 & .033 & -.225 & .025 & -.144 & -.378 \\
\hline & Compensation & .033 & 1.000 & .100 & -.222 & -.266 & -.337 \\
\hline & Memory & -.225 & .100 & 1.000 & -.069 & -.426 & .063 \\
\hline & Affective & .025 & -.222 & -.069 & 1.000 & -.069 & -.424 \\
\hline & Cognitive & -.144 & -.266 & -.426 & -.069 & 1.000 & -.023 \\
\hline & Metacognitive & -.378 & -.337 & .063 & -.424 & -.023 & 1.000 \\
\hline \multirow[t]{6}{*}{ Covariances } & Social & .082 & .003 & -.015 & .002 & -.006 & -.018 \\
\hline & Compensation & .003 & .115 & .008 & -.020 & -.014 & -.019 \\
\hline & Memory & -.015 & .008 & .056 & -.004 & -.016 & .002 \\
\hline & Affective & .002 & -.020 & -.004 & .070 & -.003 & -.018 \\
\hline & Cognitive & -.006 & -.014 & -.016 & -.003 & .024 & .000 \\
\hline & Metacognitive & -.018 & -.019 & .002 & -.018 & .000 & .027 \\
\hline
\end{tabular}

a. Dependent Variable: GEPT

To examine the amount of relationship among the independent variables (strategies), coefficient is used. For example the correlation between social and compensation is 0.033 and it is weak. Since its usual range is $(-1<r<+1)$, strong correlation (positive or negative) is a number close to 1 and -1 respectively. Social and memory strategies have negative correlation.

To illustrate the strength of the relationship between the strategies and GEPT, we use the scatter plot for each variable; although metacognitive and affective strategies are the only variables that had relationship with GEPT (Table 4), this relationship can not be recognized in the plots.

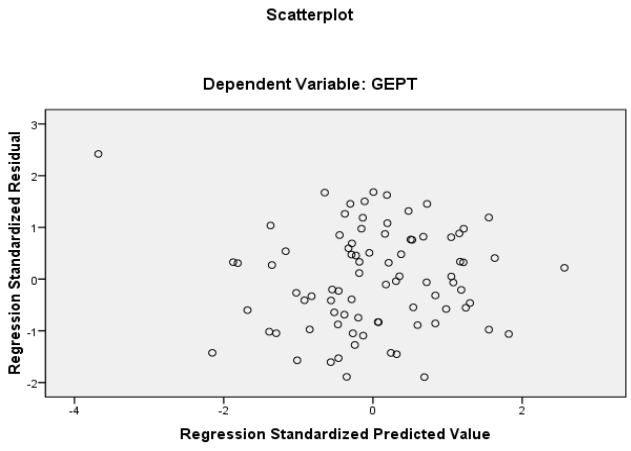

The matrix of correlation shows the whole relationship among the independent variables and GEPT (dependent variable) and among the independent variables. 


\section{CONCLUSION}

According to the independent samples $t$-test on proficiency level in Table 3, compared to lower proficiency EFL students, higher proficiency EFL students use cognitive, metacognitive and social strategies more often. The result was consistent with the finding that intermediate level students tended to use proportionally more metacognitive strategies than students with lower proficiency level proficiency (O'Malley et al., 1985) and the finding that metacognitive strategy use rose as the foreign language course level increased (Chamot et al., 1987). In contrast, there is no significant difference in the use of memory strategies between higher and lower proficiency EFL students. In addition, both higher and lower proficiency EFL students use compensation strategies more often than other strategies probably because they are the easiest to use. This finding might imply that students tried to make up for their missing knowledge by using the most direct and natural way. The result is similar to Green and Oxford (1995) who found that intermediate students used cognitive strategies significantly more than did basic students. The positive relationship between cognitive strategy use and English proficiency represents that students with a greater use of cognitive strategy have better performance on English proficiency.

In conclusion, the principal findings from this investigation include:

1. Both higher and lower proficiency EFL students use compensation strategies more often than other strategies.

2. Lower proficiency EFL students use language learning strategies as often as higher proficiency EFL students. This is perhaps because the levels of proficiency which were investigated in this study (elementary and intermediate) are not much different from each other and if the elementary level were compared with the advanced one a significant difference could be noticed (a good hypothesis for further studies).

3. The use of cognitive strategies had the strongest relation to English proficiency.

What learners know about themselves and about their own learning process can affect their use of language learning strategies (Wenden, 1986). Learners' level of strategy awareness also influences strategy use. Nyikos (1987) found that learners used only a narrow range of strategies and were generally unaware of the strategies they used. Therefore, in order to improve students' language learning, EFL teachers need to understand what language learning strategies students use and encourage lower proficiency EFL students to use language learning strategies in their learning process. Moreover, teaching methods often influence how students learn. Teachers should become more aware of their students' learning strategies in order to orient teaching methods more appropriately. This study provides the information about the difference in the extent and types of language learning strategy use between higher proficiency and lower proficiency EFL students and the strength of the effect of language learning strategy use on English proficiency. Future research should focus on methods to integrate language learning strategy training into language instruction, discovering other strategies other than the six types of language learning strategies discussed in this study might enhance students' language learning and the effect of strategy instruction on language learning.

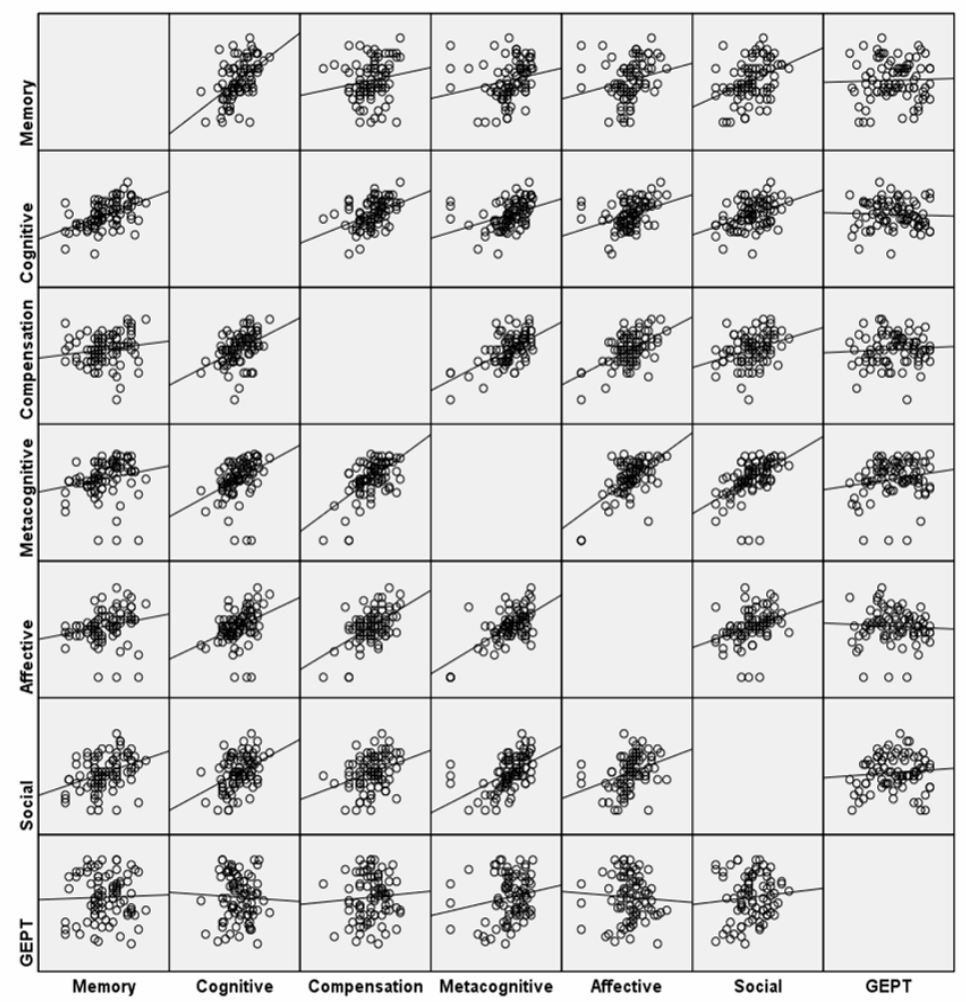




\section{APPENDIX A STRATEGy INVENTRY FOR LANGUAGE LEARNING (SILL)}

This form of the strategy inventory for language learning (SILL) is for students of English as a second or foreign language. You will find statements about learning English. Please read each statement and write the response (1, 2, 3, 4, or 5) that tells HOW TRUE THE STATEMENT IS.

1. Never or almost never true of me

2. Usually not true of me

3. Somewhat true of me

4. Usually true of me

5. Always or almost always true of me

Answer in terms of how well the statement describes you. Do not answer how you think you should be, or what other people do. There are no right or wrong answers to these statements. This questionnaire usually takes about 20-30 minutes to complete. If you have any questions, let the teacher know immediately.

\section{Part A}

1. I think of relationships between what I already know and new things I learn in English.

2. I use new English words in a sentence so I can remember them.

3. I connect the sound of a new English word and an image or picture of the word to help me remember the word.

4. I remember a new English word by making a mental picture of a situation in which the word might be used.

5. I use rhymes to remember new English words.

6. I use flashcards to remember new English words.

7. I physically act out new English words.

8. I review English lessons often.

9. I remember new English words or phrases by remembering their location on the page, on the board, or on a street sign.

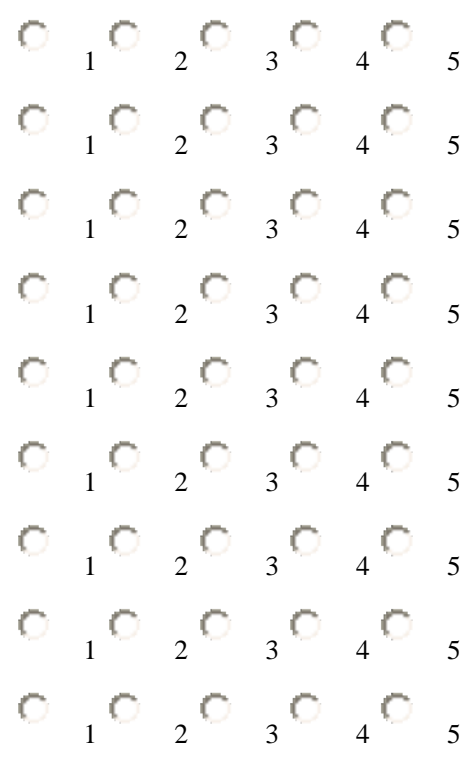

\section{Part B}

10. I say or write new English words several times.

11. I try to talk like native English speakers.

12. I practice the sounds of English.

13. I use the English words I know in different ways.

14. I start conversations in English.

15. I watch English language TV shows spoken in English or go to movies spoken in English.

16. I read for pleasure in English.

17. I write notes, messages, letters, or reports in English.

18. I first skim an English passage (read over the passage quickly) then go back and read carefully.

19. I look for words in my own language that are similar to new words in English.

20. I try to find patterns in English.

21. I find the meaning of an English word by dividing it into parts that I understand.

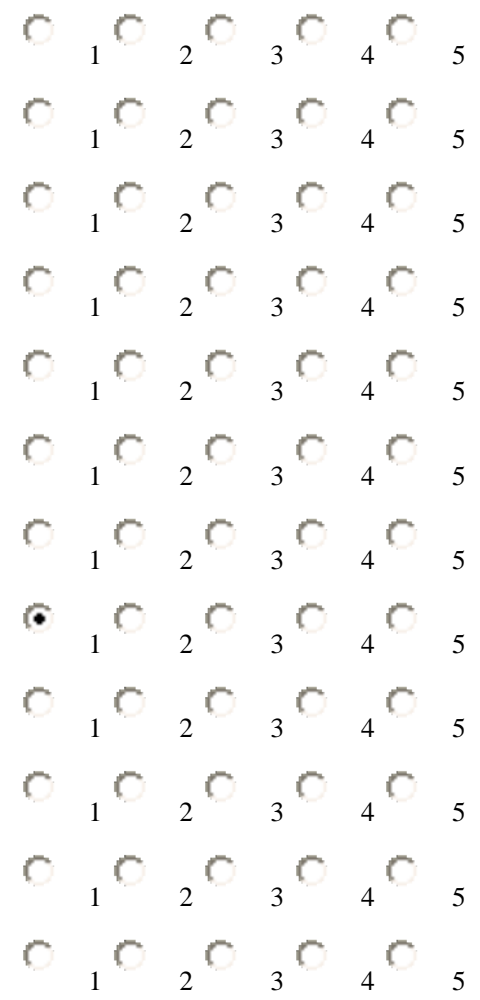


22. I try not to translate word for word

23. I make summaries of information that I hear or read in English.

\section{Part C}

24. To understand unfamiliar English words, I make guesses.

25. When I can't think of a word during a conversation in English, I use gestures.

26. I make up new words if I do not know the right ones in English.

27. I read English without looking up every new word.

28. I try to guess what the other person will say next in English.

29. If I can't think of an English word, I use a word or phrase that means the same thing.

\section{Part D}

30. I try to find as many ways as I can to use my English.

31. I notice my English mistakes and use that information to help me do better.

32. I pay attention when someone is speaking English.

33. I try to find out how to be a better learner of English.

34. I plan my schedule so I will have enough time to study English.

35. I look for people I can talk to in English.

36. I look for opportunities to read as much as possible in English.

37. I have clear goals for improving my English skills.

38. I think about my progress in learning English.

\section{Part E}

39. I try to relax whenever I feel afraid of using English.

40. I encourage myself to speak English even when I am afraid of making a mistake.

41. I give myself a reward or treat when I do well in English.

42. I notice if I am tense or nervous when I am studying or using English.

43. I write down my feelings in a language learning dairy.

44. I talk to someone else about how I feel when I am learning English.

Part F

45. If I do not understand something in English, I ask the other person to slow down or say it again.

46. I ask English speakers to correct me when I talk.

47. I practice English with other students.
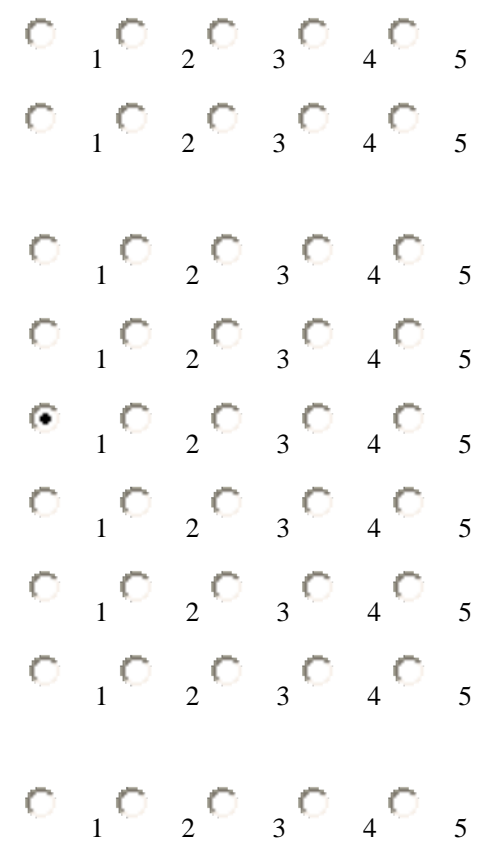

r.

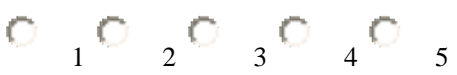

C.

C $142 \pi$

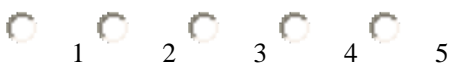

C 12405

C. 1253

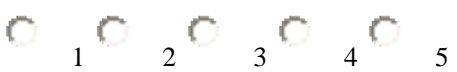

r $r_{2} 3^{r} r_{5}$

C 1 r 345

C 1 r 2 r 35

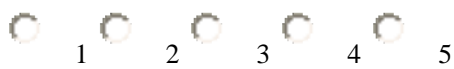

r 1 r $33_{4}$

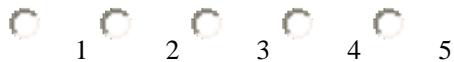

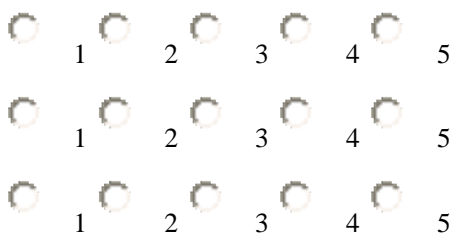


48. I ask for help from English speakers.

49. I ask questions in English.

50. I try to learn about the culture of English speakers.

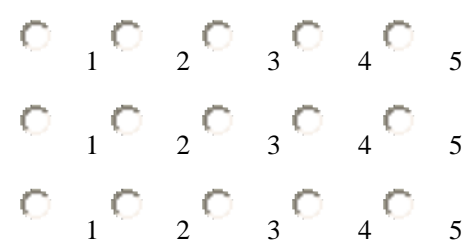

$$
\text { Class School ID }
$$

\section{REFERENCES}

[1] Abraham, R. \& Vann, R. (1087). Strategies of Two Language Learners: A Case Study. In A. L.Wenden and J. Rubin (eds.), Learner strategies in language learning. London: Prentice Hall International.

[2] Bialystok, E. (1979). The role of conscious strategies in second language proficiency. Canadian Modern Language Review, 35, 372-394.

[3] Chamot, A., \& Kupper, L. (1989). Learning strategies in foreign language instruction. Foreign Language Annals, $22,13-24$.

[4] Chamot, A., O’Malley, J. M., Küpper, L., \& Impink-Hernandez, M. V. (1987). A study of learning strategies in foreign language instruction: First year report. Rosslyn, VA: InterAmerican Research Associates.

[5] Cohen, A. D., (1998). Strategies in Learning and Using a Second Language. London: Longman.

[6] Ehrman, M., \& Oxford, R. (1989). Effects of sex differences, career choice, and psychological type on adult language learning strategies. Modern Language Journal, 73, 1-13.

[7] Elli, R. (1994). The Study of Second Language Acquisition. Oxford: Oxford University Press.

[8] MacIntyre, P. D., \& Neols, K. A. (1994). Using Social-psychological variables to predict the use of language learning strategies. Foreign Language Annals, 29, 383-386.

[9] Naiman, N., Frolich, M., \& Todesco, A., (1975).The Good Language Learner. TESL Talk, 6, 68-75.

[10] Naiman, N., Frolich, M., Stern, H., \& Todesco, A., (1978).The Good Language Learner. Research in Education Series 7. Toronto: OISE Press.

[11] Nyikos, M. (1987). The effect of color and imagery as mnemonic strategies on learning and retention of lexical items in German. Unpublished doctoral dissertation, Purdue University, West Lafayette, IN.

[12] O’Malley, J. M., \& Chamot, A. U. (1990). Learning strategies in second language acquisition. Cambridge: Cambridge University Press.

[13] O’Malley, J., Chamot, A., Stewner-Manzanares, G., Kupper, L., \& Russo, R. (1985). Learning strategies used by beginning and intermediate ESL students. Language Learning, 35, 21-46.

[14] Oxford, R. L. (1989). Use of language learning strategies: A synthesis of studies with implications for strategy training. System, $17,235-247$.

[15] Oxford, R. L. (1990). Language learning strategies: What every teacher should know. New York: Newbury House Publishers.

[16] Oxford, R. L., Stock, B., J., (1995). Assessing the Use of Language Learning Strategies Worldwide with the ESL/EFL Version of the Strategy Inventory for Language Learning (SILL). System 23, 1, 1-23.

[17] Oxford, R. L., \& Crookall, D. (1989). Research on second language learning strategies: Methods, findings, and instructional issues. Modern Language Journal, 73, 404-419.

[18] Oxford, R. (1993). Research on second language learning strategies. Annual Review of Applied Linguistics, 13, $175-187$.

[19] Oxford, R., \& Nyikos, M. (1989). Variables affecting choice of language learning strategies by university students. Modern Language Journal, 73, 291-300.

[20] Politzer, R. (1983). An exploratory study of self reported language learning behaviors and their relation to achievement. Studies in Second Language Acquisition, 6, 64-67.

[21] Politzer, R. L., \& M. McGroarty. (1985). An exploratory study of learning behaviors and their relation to gains in linguistic and communicative competence. TESOL Quarterly, 19, 103-123.

[22] Reiss, M. (1983). Helping the Unsuccessful Language Learner. The Canadian Modern Language Review 39: 257-66.

[23] Rubin, J. (1975). What the "good language learner" can teach us. TESOL Quarterly, 9, 41-51.

[24] Stern, H.H. (1975). What can we learn from the good language learner? Canadian Modern Language Review, 31, $304-18$.

[25] Weistein, C. E., \& Mayer, R. E. (1986). The teaching of learning strategies. In M. C. Wittrock (Ed.), Handbook of research on teaching (3rd ed., pp. 315-327).

[26] Wenden, A. (1985). Learner Strategies. TESOL Newsletter 19 (5): 1-7.

[27] Wenden, A. (1986). What do second-language learners know about their language learning? A second look at retrospective accounts. Applied Linguistics, 7, 186-205.

[28] Yang, N. D. (1994). Second Language Learner's Beliefs about Language Learning and Their Use of learning strategies: A Study of College Student of English in Taiwan. PhD. Diss., University of Texas, Austin.

Maryam Khosravi. MA in TEFL (Teaching English as a Foreign Language), Sheikhbahaee University, Isfahan, Iran. 2010.

She has worked with Iran Language Institute (ILI) in Isfahan since 2011 and Sheikhbahaee University, Baharestan, Isfahan as an English teacher since 2009. She also has job experience as an English teacher and educational supervisor in Nahid Cultural Institute since 2000. 